Celebes Abdimas: Jurnal Pengabdian Kepada Masyarakat

http://journal.lldikti9.id/CER/index

Vol 2, No, 2, Oktober 2020, pp 80-85

p-ISSN:2656-7938 dan e-ISSN: 2657-1870

DOI: https://doi.org/10.37541/celebesabdimas.v2i2.484

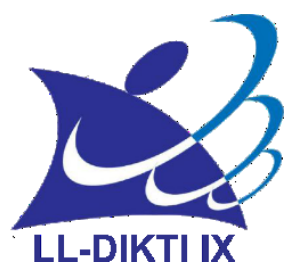

\title{
Peningkatan Kemampuan Orang Tua dalam Pengembangan Moralitas Anak Melalui Modelling di Paud Desa Layak Anak
}

\author{
Purwati ${ }^{1}$ Muhammad Japar, ${ }^{2}$ \\ ${ }^{1}$ Fakultas Keguruan dan Ilmu Pendidikan, Universitas Muhammadiyah Magelang, Indonesia \\ Email: bupurwati@gmail.com \\ ${ }^{2}$ Fakultas Keguruan dan Ilmu Pendidikan, Universitas Muhammadiyah Magelang, Indonesia \\ Email: jafarmuh@gmail.com
}

\section{Artikel info}

\section{Article history:}

Received: 29-08-2020

Revised: $18-09-2020$

Accepted: $10-10-2020$

Publish: 28-10-2020
Abstrak. Tujuan dari pengabdian adalah untuk meningkatkan kemampuan dan keterampilan orang tua dalam membentuk dan mengembangkan moralitas anak di Desa Menayu Kecamatan Muntilan, kabupaten Magelang, demi mewujudkan "Desa Layak Anak ". Metode yang digunakan adalah Rural Apraissal, dengan pendekatan dalam proses pemberdayaan dan peningkatan partisipasi masyarakat, yang tekanannya pada keterlibatan masyarakat dalam keseluruhan kegiatan. Orang tua yang dilibatkan dalam kegiatan pengabdian ini sebanyak 50 orang. Hasil yang diperoleh dari kegiatan pengabdian ini yaitu terjadinya peningkatan kemampuan dan keterampilan orang tua dalam membentuk dan mengembangkan moralitas anak. Kesimpulan, meningkatnya kemampuan dan ketrampilan orang tua dalam mengembangkan moralitas anak dapat mewujudkan Desa Menayu sebagai Desa Layak Anak.

Abstract. The purpose of this service is to improve the abilities and skills of parents in shaping and developing children's morality in Menayu Village, Muntilan District, Magelang Regency, in order to create a "Child Friendly Village". The method used is Rural Apraissal, with an approach to the empowerment process and increasing community participation, which emphasizes community involvement in all activities. As many as 50 parents were involved in this service activity. The results obtained from this service activity are an increase in the ability and skills of parents in shaping and developing children's morality. In conclusion, increasing the abilities and skills of parents in developing children's morality can make Menayu Village a ChildFriendly Village.

Coresponden author: Purwati

Orang Tua Moralitas Anak; Modeling; DLA
Universitas Muhammadiyah Magelang, Indonesia Email: bupurwati@gmail.com

artikel dengan akses terbuka dibawah lisensi CC BY 4.0 


\section{1| Celebes Abdimas: Jurnal Pengabdian Kepada Masyarakat}

\section{PENDAHULUAN}

Desa layak anak (DLA) merupakan suatu pembangunan desa dengan menyatukan sumber daya dan komitmen pemerintah desa yang melibatkan warga dan badan usaha yang berada di desa, untuk mempromosikan, melindungi, memenuhi dan menghormati hak-hak anak (Menteri, 2011). Desa layak anak sangat penting diwujudkan untuk mendukung perlindungan dan tumbuh kembang anak serta mewujudkan tempat tinggal anak atau desa sebagai media bibit sumber daya manusia yang unggul dan berkualitas(Rumtianing, 2014). Tujuan dari DLA untuk meningkatkan kepedulian dan upaya konkrit desa dalam upaya mewujudkan desa yang menjamin pembangunan pemenuhan hak-hak anak, memastikan pembangunan desa dengan memperhatikan kebutuhan anak, aspirasi dan kepentingan terbaik bagi anak(Subiyakto, 2012). Pembangunan desa yang dilakukan juga tidak memberikan diskriminasi terhadap anak, termasuk anak bebas bullying. Selain itu juga menyatukan potensi dan realisasi Sumber Daya Manusia, sumberdaya alam, sumber dana, sarana, prasarana, metoda dan teknologi, serta partisipasi masyarakat yang ada pada pemerintahan desa. Salah satu indicator desa layak anak adalah klaster perlindungan khusus. Dikatakan sudah memenuhi klaster tersebut jika desa sudah mampu memberikan perlindungan terhadap anak, memberikan ruang atau lingkungan yang kondusif dalam perkembangan anak dan memenuhi hak-hak anak (Arifin, 2016). Dengan dapat dicegahnya bullying pada anak, diharapkan anak akan mendapatkan haknya untuk memperoleh standar kehidupan yang layak agar bisa berkembang secara optimal, baik fisik, mental, spiritual, moral maupun sosial dengan baik (Rumtianing, 2014). Perilaku bermoral sangat dibutuhkan dalam perwujudan desa layak anak.

Anak merupakan manusia yang selalu tumbuh dan berkembangan dengan mempunyai karakteristik dalam setiap tahapan perkembangan. Usia dini, menurut The National Association for The Education of Young Children (NAEYC), adalah usia sejak lahir sampai usia delapan tahun (Bredekamp, 1992). Berdasarkan pasal 1 ayat 14 UU No. 20 tahun 2003 tentang Sistem Pendidikan Nasional (Departemen Pendidikan Nasional, 2003), anak usia dini adalah usia pada saat anak baru lahir sampai dengan usia 6 tahun. Periode anak usia dini merupakan tahap awal kehidupan individu yang akan menentukan sikap, nilai, perilaku, dan kepribadian individu di masa depan. Pada usia tersebut semua aspek perkembangan berkembang secara progresif, yang meliputi fisik, kognitif dan psikososial (Papalia dkk., 2002). Stimulasi yang diberikan kepada anak usia dini akan mengoptimalkan semua potensi perkembangan yang pada akhirnya akan memengaruhi keberhasilan dalam penyesuaian diri.

Aspek moral merupakan salah satu aspek perkembangan yang perlu distimulasi secara maksimal, sehingga anak akan berperilaku sesuai dengan nilai-nilai moral yang berlaku. Perilaku bermoral atau moralitas sangat diperlukan dalam hidup bermasyarakat, berbangsa dan bernegara. Menurut Piaget (Sinolungan, 1997), moralitas merupakan kecenderungan untuk menerima dan mematuhi system aturan. Sedangkan menurut Kohlberg (Gunarsa, 1993), mengatakan bahwa moral adalah sesuatu yang tidak dibawa dari lahir, tetapi sesuatu yang dikembangkan dan dibentuk serta dipelajari melalui lingkungan dimana anak itu hidup. Lingkungan dalam hal ini mempunyai peran penting dalam pembentukan dan pengembangan moral. Perilaku bermoral merupakan perilaku yang didasarkan pada nilai-nilai yang berlaku di masyarakat, sebaliknya perilaku yang tidak bermoral adalah perilaku yang tidak sesuai dengan nilai-nilai masyarakat setempat. Perilaku moral pada dasarnya adalah perilaku seseorang dalam berhubungan dengan orang lain yang mengacu pada seperangkat peraturan, kebiasaan, dan prinsip-prinsip tertentu yang berdampak pada kesejahteraan manusia (Mini, 2008).

Perilaku moral anak atau moralitas anak dapat dipengaruhi oleh banyak factor. Santrock, (2003), berpendapat bahwa factor yang mempengaruhi moralitas anak yaitu : (a), Modeling, (b), situasional, (c) lingkungan dan (d) diri. Berdasarkan pada pendapat Santrock tersebut bahwa dengan jelas bahwa moralitas anak dibentuk dan dikondisikan dari lingkungan dimana anak berada. Lingkungan yang dimaksud meliputi lingkungan keluarga, lingkungan masyarakat dan lingkungan sekolah.

Orang tua merupakan pendidik pertama dan utama di lingkungan keluarga. Tugas dan tanggungjawab keluarga cukup besar dan tidak bisa digantikan oleh orang lain terkait dalam pembentukan dan pengembangan moralitas anak. Baik buruknya perilaku anak akan sangat 
tergantung dari totalitas dan keberadaan orang tua di lingkungan keluarga. Sikap dan perilaku orang tua dalam keseharian yang terwujud dalam pola asuhan akan mempengaruhi pembentukan moralitas anak. Anak setiap waktu mengamati dan menginternalisasi apa yang dilihat pada orang tua . Menurut Albert Bandura (1986), proses mengamati terhadap model akan diinternalisasi dalam dirinya. Selanjutnya dikatakan bahwa dari perspektif teori pembelajaran social, modeling merupakan salah satu bentuk pembentukan moralitas dengan cara mengobervasi terhadap model yang dihadapi. Selanjutnya dikatakan bahwa pembentukan moral pada anak melalui tahapan-tahapan sebagai berikut : (a) Tahap perhatian (attentional phase), (b) Tahap penyimpanan dalam ingatan (retention phase), (c) Tahap reproduksi (reproduction phase) dan (d) tahap motivasi (motivation phase). Teori belajar social menekankan bahwa pada proses bagaimana anak-anak belajar norma-norma social atau kemasyarakatan.

\section{METODE}

Metode yang digunakan dalam pengabdian ini adalah pemberdayaan masyarakat partisipatif dengan model Participatory Rural Apraissal yaitu suatu metode pendekatan dalam proses pemberdayaan dan peningkatan partisipasi masyarakat, yang tekanannya pada keterlibatan masyarakat dalam keseluruhan kegiatan yang dilaksanakan. Dalam pengabdian ini, mitra adalah pokja pkk di bebrapa dusun, yaitu dusun kepanjen, dusun sorogenen dan dusun jambean. Mitra tersebut mempunyai kompetensi standar, yaitu berpendidikan minimal setingkat smp, jumlah kader tiap pokja minimal 10 orang, telah memiliki pengalaman dalam pokja pkk selama lebih dari 5 tahun baik dibidang social, ekonomi, budaya, kesehatan maupun pendidikan. Tim yang melaksanakan pengabdian ini adalah tim dari Fakultas llmu Pendidikan dan Fakultas Ilmu Kesehatan, yang memiliki sara dan prasarana yang mendukung program pengabdian.

Dari Metode PRA yang digunakan dalam pengabdian ini ada 3 tahap. Tahap pertama yaitu Pengenalan masalah atau kebutuhan dan potensi serta penyadaran. Dalam tahap ini dilakukan identifikasi terhadap berbagai permasalahan yang dihadapi mitra pada semua indikator DLA. Metode untuk melakukan identifikasi adalah dengan observasi dan wawancara dengan pihakpihak terkait yaitu kepala Desa Menayu, kelompok mitra yaitu bidan desa dan Pokja PKK, dan Dinas Kesehatan, Dinas Pendidikan. Tahap kedua adalah Perumusan masalah dan penetapan prioritas.

Hasil permasalahan yang sudah teridentifikasi selanjutnya didiskusikan melalui FGD dengan ketiga kelompok mitra (Pokja PKK Dusun Kepanjen, Dusun Sorogenen, Dusun Jambean) maupun BAPPEDA, DPPKAD, Bagian TAPEM, Camat, UPT KBKS, Kepala Desa, Bidan Desa untuk menentukan prioritas permasalahan yang akan diselesaikan selama 3 tahun dalam program PPDM ini. Tahap ketiga adalah Identifikasi alternatif-alternatif pemecahan masalah atau pengembangan gagasan. Diskusi antara tim pengusul, mitra, dan BAPPEDA, DPPKAD, Bagian TAPEM, Camat, UPT KBKS, Kepala Desa, Bidan Desa. Pemerintah kecamatan Muntilan juga diterapkan pada penentuan alternatif-alternatif pemecahan masalah yang sudah diprioritaskan.

\section{HASIL DAN PEMBAHASAN}

Berdasarkan observasi dan wawancara dengan mitra, terdapat beberapa permasalahan yang teridentifikasi. Permasalahan tersebut yaitu, masyarakat khususnya orang tua tidak mengetahui mengenai pembentukan karakter yang baik, pembentukan dan pengembangan moral anak , serta belum memahami apa yang harus dilakukan untuk pengembangkan moral anak di usia dini. Masih banyak anak yang melakukan perilaku-perilaku melanggar norma dan moral yang diyakini oleh masyarakat. Berpijak dari permasalahan tersebut, selanjutkan didiskusikan dan ditentukan strategi atau teknik untuk pengembangan moral anak sejak dini. 
83| Celebes Abdimas: Jurnal Pengabdian Kepada Masyarakat
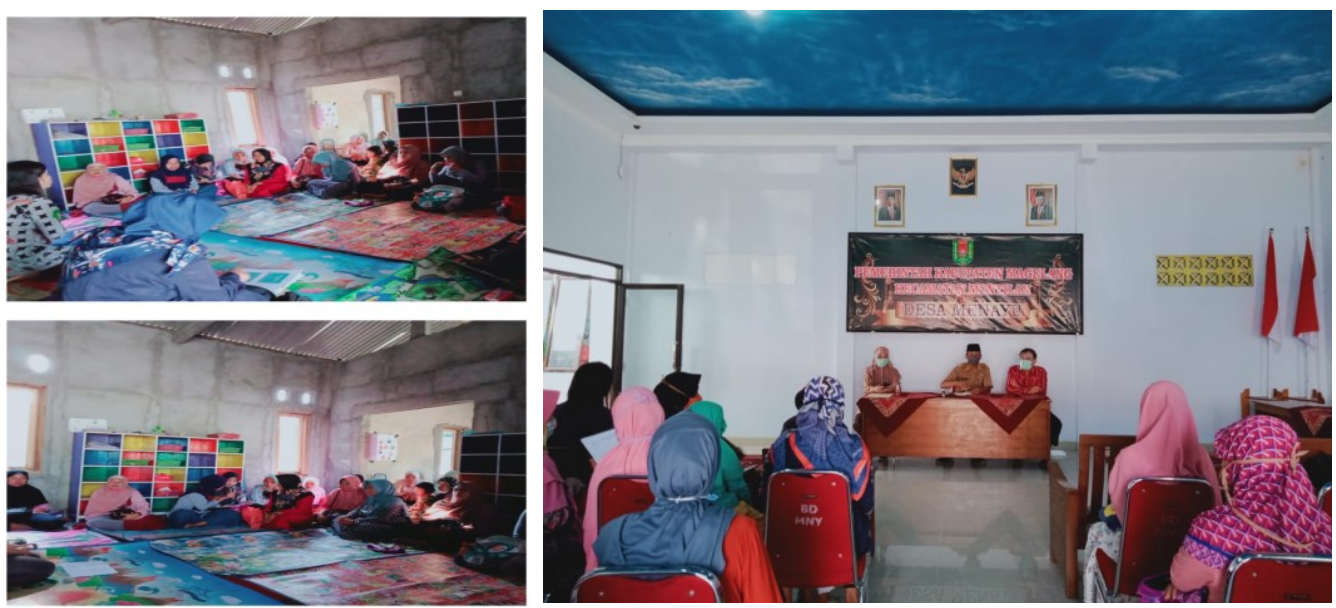

Gambar 1. Kegiatan pemberian penyuluhan tentang pengembangan moral pada anak.

Gambar tersebut di atas menunjukkan kegiatan parenting yang ditujukan kepada para orang tua dan juga dilakukan pemberian informasi kepada kader terkait dengan pentingnya "Pendidikan Anak Usia Dini" yang ditujukan kepada kader, pendidik, pengelola Kelompok bermain Tunas Bangsa Desa menayu, Kecamatan Muntilan Kabupaten Magelang. Kegiatan dilakukan secara rutin dan terjadwal.

Kegiatan penyuluhan tentang strategi pengembangan moral anak, dilakukan tidak hanya ditujukan kepada orang tua saja, tetapi juga ditujukan kepada pendidik Kelompok Bermain Tunas Bangsa Desa Menayu, Pengelola KB, kader Posyandu dan PKK. Hal ini disadari bahwa moral anak dipengaruhi oleh banyak factor . Smetana (1999), melakukan analisis teori domain sosial tentang peran orang tua dalam perkembangan moral. Domain pengetahuan sosial, termasuk moralitas dibangun dari interaksi sosial timbal balik, baik komponen afektif dan kognitif dari interaksi orang tua dengan anak-anak, Orang tua dapat memfasilitasi perkembangan moral anak-anak. Konteks hubungan afektif dapat mempengaruhi motivasi anak-anak untuk mendengarkan dan merespon orang tua; di samping itu, mempengaruhi tanggapan terhadap pelanggaran dapat mempengaruhi encoding anak-anak dan mengingat peristiwa-peristiwa. Orang tua mempromosikan pemahaman moral anak-anak dengan menyediakan domain yang tepat, penalaran perkembangan sensitif dan penjelasan tentang dunia sosial anak, yang dapat merangsang perkembangan pemikiran moral yang lebih matang. Berikut hasil kegiatan pemberian penyuluhan dalam rangka pengembangan moral anak.

Tabel 1: Nilai pretest- dan post test

\begin{tabular}{crcc}
\hline Subyek/peserta. & $\begin{array}{c}\text { Nilai } \\
\text { Pretest }\end{array}$ & $\begin{array}{c}\text { Nilai } \\
\text { Posttest }\end{array}$ & $\begin{array}{c}\text { Hasil Kenaikan } \\
\text { Tes }\end{array}$ \\
\hline 01 & 75 & 86 & 11 \\
02 & 74 & 90 & 16 \\
03 & 80 & 93 & 13 \\
04 & 79 & 90 & 11 \\
05 & 70 & 88 & 18 \\
06 & 73 & 89 & 16 \\
07 & 76 & 90 & 14 \\
08 & 72 & 88 & 16 \\
09 & 80 & 90 & 10 \\
10 & 81 & 92 & 11 \\
11 & 83 & 90 & 7 \\
12 & 80 & 89 & 9 \\
13 & 79 & 90 & 11 \\
14 & 78 & 89 & 11
\end{tabular}




\begin{tabular}{llll}
15 & 77 & 89 & 12 \\
16 & 79 & 90 & 11 \\
17 & 80 & 90 & 10 \\
18 & 79 & 89 & 10 \\
19 & 76 & 89 & 13 \\
20 & 80 & 91 & 11 \\
\hline
\end{tabular}

Berdasarkan hasil analisis data sebelum dan sesudah dilakukan penyuluhan dan pelatihan kepada orang tua, sekaligus kepada pendidik serta pengelola terdapat kenaikan . Kenaikan tersebut dilihat dari rerata (mean) sebelum dan sesudah dilakukan kegiatan pengabdian. Sebelum dilakukan kegiatan pengabdian (penyuluhan) rerata (mean) adalah 77.55, setelah dilakukan penyuluhan dengan teknik ceramah diperoleh rerata 89.6 , sehingga rerata peningkatan dari sebelum dan setelah dilakukan kegiatan pengabdian dengan berbagai metode yaitu 12.05. Hal tersebut menunjukkan bahwa dengan pemberian penyuluhan yang berupa pengetahuan dan keterampilan orang tua tentang moralitas melalui modeling meningkat. Kegiatan pengabdian ini dilakukan selain dengan ceramah . orang tua juga melakukan praktek langsung terhadap anaknya. Kegiatan praktek tersebut melalui sikap dan perilaku orang tua yang menunjukkan nilai-nilai moral dalam kehidupan keseharian di rumah. Hal ini merupakan teknik modeling yang harus dilakukan orang tua dihadapan anak di lingkungan keluarga. Anak diharapkan dapat mengamati sikap dan perilaku orang sehingga hal akan terjadi internalisasi dalam diri anak. Setelah lebih kurang dua minggu, selanjutnya orang tua diberikan instrument tentang pemahaman moral dengan tujuan untuk mengetahui sejauh mana tingkat pemahaman orang tua mengenai pengembangan moral melalui modeling terhadap anak. Evaluasi tersebut selain mengguakan instrument angket juga menggunakan observasi dan wawancara langsung kepada orang tua.

Pemberian materi tentang pengembangan moral anak melalui modeling dapat meningkatkan kemampuan orang tua dalam berhubungan dan mendidik putera-puterinya di keluarga. Hal ini dapat dibuktikan dari hasil analisis data dengan waktu dua minggu orang tua memahami tentang pengembangan nilai-nilai moral anak melalui proses modeling. Proses pengembangan moral dapa dilakukan melalui keteladanan, penting bagi orang tua untuk menjadi teladan sekaligus model atau memposisikan diri sebagai model bagi anak. Pengembangan moral melalui modeling dapat diyakini berpenagruh besar bagi moralitas anak. Dalam proses modeling atau keteladanan, anak mengamati atau melihat perilaku orang tua, informasi yang diperoleh melalui pengamatan diteruskan ke cortex untuk diproses, hasil pemrosesan informasi dapat digunakan langsung untuk berperilaku dan dapat juga disimpan dalam ingatan untuk digunakan berperilaku pada kesempatan yang akan datang (Bandura dalam Petri, 1981).

Keluarga merupakan masyarakat terkecil dan dalam keluarga terjadi interaksi awal antara anak dengan orang tua dan anggota keluarga lainnya. Pendidikan anak berawal dalam keluarga melalui pola asuh orang tua. Dalam pelaksanaan pola asuh, peran orang tua sangat penting dan strategis. Tingkat Pendidikan dan pengetahuan, atensi, dan komitmen orang tua sangat menentukan proses dan hasil parent rearing practice. Salah satu aspek penting dalam parent rearing practice adalah Pendidikan moral bagi anak.

Diberikannya pelatihan, penyuluhan tentang moral anak (pengembangan dan peningkatannya), membuat para orang mengetahui tentang bagaimana strategi dan cara untuk mengembangkan moralitas anak melalui modeling. Orang tua paham tentang apa yang harus dilakukan dihadapan anak-anak, bagaimana harus bersikap dan berilaku, bagaimana harus berbicara, bagaimana harus melayani dan mengasuh anak-anak mereka. Hal ini lah yang membuat dan mewujudkan Desa Menayu menjadi Desa Layak Anak. Pada dasarnya pengembangan moral pada anak menurut Kohlberg melalui tahapan perkembangan (McMahon et.al., 1995, dan Papaliaet.el., 2002) yaitu : (1) tingkat prakonvensional - usia lahir sampai 6 tahun, (2) konvensional - usia 7-11 tahun, dan (3) pascakonvensional - usia 11 tahun ke atas. 
85| Celebes Abdimas: Jurnal Pengabdian Kepada Masyarakat

\section{SIMPULAN DAN SARAN}

Moralitas anak merupakan bentuk perilaku anak yang menunjukkan baik atau buruk, benar atau salah berdasarkan pada nilai-nilai dianut atau dipercayai oleh kelompok msyarakat tertentu. Perilaku moral anak pada dasarnya dibentuk dan dikondisikan oleh lingkungan terutama oleh orang tua. Orang tua mempunyai peran dalam mengembangkan moralitas anak sesuai ajaran dan keyakinan yang dianut serta nilai-nilai yang berlaku di masyarakat. Kegiatan penyuluhan dan pendampingan terhadap orang tua mengenai cara pengembangan moral anak melalui modeling, mampu meningkatkan pemahaman dan pengetahuan orang tua. Dalam proses modeling atau keteladanan, anak mengamati atau melihat sika dan perilaku orang tua, informasi yang diperoleh melalui pengamatan diteruskan ke cortex untuk diproses, hasil pemrosesan informasi dapat digunakan langsung untuk berperilaku dan dapat juga disimpan dalam ingatan untuk digunakan berperilaku pada kesempatan yang akan datang. Pengembangan moral anak melalui proses modeling yang ditunjukkan oleh orang tua cukup berperan dan berkontribusi terhadap pengembangan moral pada anak.

Pengembangan moral pada anak harus dimulai sejak dini agar poses internalisasi nilainilai moral benar-benar terjadi pada diri anak. Pada masa anak, terjadi perkembangan pada semua aspek, termasuk salah satu adalah aspek moral-spritual.

\section{DAFTAR RUJUKAN}

Albert Bandura. (1986). Social foundations of thought and action: A social cognitive theory. Englewood. Cliffs, NJ: Prentice-Hall.

Bredekamp, S. (Ed.). 1992. Developmentally Appropriate Practice in Early Childhood Program Serving Children from Birth through Age 8. Washington, DC: NAEYC.

Departemen Pendidikan Nasional. 2003. Undang-undang Republik Indonesia 2003 Nomor 20 tentang Sistem Pendidikan Nasional. Jakarta: Departemen Pendi- dikan Nasional, Direktorat Jenderal Pendidikan Da- sar dan Menengah.

Gurnasa, D, Singgih. 1993. Psikologi Perkembangan Anak dan Remaja. BPK. Gunung Mulia. Jakarta

McMahon, J.W., McMahon, F.B., dan Romano, T. 1995. Psychology and You. Second ed. New York: West Publishing Company

Mini, Rose. 2008. Perilaku anak usia dini kasus dan pemecahannya. Yogyakarta: Kansius.

Santrock. 2003. Perkembangan Remaja. Jakarta: Erlangga

Sinolungan, A.E. 1997. Psikologi Perkembangan Peserta Didik. Gunung Agung. Jakarta

Smetana, J. G. (1999). The Role of Parents in Moral Development: A social domain analysis. Journal of Moral Education, 28 (3), 311-321. https://doi.org/10.1080/030572499103106 